University of Nebraska - Lincoln

DigitalCommons@University of Nebraska - Lincoln

\title{
Geochemical Variations in Peoria Loess of Western lowa Indicate Paleowinds of Midcontinental North America during Last Glaciation
}

Daniel R. Muhs

US. Geological Survey, dmuhs@usgs.gov

E. Arthur Bettis III

University of lowa, art-bettis@uiowa.edu

Follow this and additional works at: https://digitalcommons.unl.edu/usgsstaffpub

Part of the Earth Sciences Commons

Muhs, Daniel R. and Bettis, E. Arthur III, "Geochemical Variations in Peoria Loess of Western lowa Indicate Paleowinds of Midcontinental North America during Last Glaciation" (2000). USGS Staff -- Published Research. 186.

https://digitalcommons.unl.edu/usgsstaffpub/186

This Article is brought to you for free and open access by the US Geological Survey at DigitalCommons@University of Nebraska - Lincoln. It has been accepted for inclusion in USGS Staff -- Published Research by an authorized administrator of DigitalCommons@University of Nebraska - Lincoln. 


\title{
Geochemical Variations in Peoria Loess of Western lowa Indicate Paleowinds of Midcontinental North America during Last Glaciation
}

\author{
Daniel R. Muhs \\ U.S. Geological Survey, MS 980, Box 25046, Federal Center, Denver, Colorado 80225 \\ and \\ E. Arthur Bettis, III \\ Department of Geoscience, University of Iowa, Iowa City, Iowa 52242
}

Received December 7, 1998

Peoria Loess deposited in western Iowa during the last glacial maximum (LGM) shows distinct geochemical and particle-size variations as a function of both depth and distance east of the Missouri River. Geochemical and particle-size data indicate that Peoria Loess in western Iowa probably had two sources: the Missouri River valley, and a source that lay to the west of the Missouri River. Both sources indicate that LGM paleowinds in western Iowa had a strong westerly component, similar to interpretations of previous workers. A compilation of loess studies in Iowa and elsewhere indicates that westerly winds were dominant during loess transport over much of the midcontinent south of the Laurentide ice sheet, which is not in agreement with paleowinds simulated by atmospheric general circulation models (AGCMs). AGCMs consistently generate a glacial anticyclone with easterly or northeasterly winds over the Laurentide ice sheet and the area to the south of it. Loess deposition in the midcontinent during the LGM may be a function of infrequent northwesterly winds that were unrelated to the presence of the glacial anticyclone. (๑) 2000 University of Washington.

Key Words: loess; Iowa; North American midcontinent; last glacial maximum; paleowinds; climate models.

\section{INTRODUCTION}

Loess is a ubiquitous surficial geologic deposit over much of the North American midcontinent and forms the parent material for some of the most agriculturally productive soils in the world. Recently, there has been a growing appreciation of the paleoclimatic significance of thick loess sequences with their intercalated paleosols. Some of these records are considered the best continental analog of the deep-sea oxygen isotope record as a paleoclimatic record of glacial-interglacial cycles (e.g., Hovan et al., 1989).

An underappreciated aspect of the value of loess to paleoclimatic studies is that eolian silt is a direct record of atmospheric circulation. Atmospheric general circulation models
(AGCMs) provide simulations of past, present, and future climates on global or regional scales. Because these models are simplified reconstructions of the atmosphere, they require comparison with empirically based reconstructions. The geologic record of past climates is one of the best means by which such comparisons can be made. One of the most commonly modeled periods of the past is the last glacial maximum (LGM), which peaked about 21,000 cal yr B.P. The most extensive loess deposits, on a global scale, are also those that date from the LGM. Comparisons of last-glacial atmospheric circulation derived from AGCM simulations and eolian records have been reported for Europe (Isarin et al., 1997; Zeeberg, 1998), but have yet to be made for North America.

In this paper, we reexamine the loess deposits of western Iowa for the purpose of reconstructing LGM paleowinds and comparing them to AGCM simulations. We studied one of the thickest LGM loess deposits in North America, the Loveland paratype locality in western Iowa (Daniels and Handy, 1959; Bettis, 1990; Forman et al., 1992), in order to see how loess properties may have changed over the course of the last glacial period. We also reexamined a transect of loess localities east of the Missouri River, along railroad cuts that had previously been studied by Ruhe (1954, 1969, 1983).

\section{LOESS STRATIGRAPHY AND GEOCHRONOLOGY IN WESTERN IOWA}

Loess is distributed widely over much of Iowa (Figs. 1 and 2). Three loess units have been identified in western Iowa based on detailed stratigraphic studies by Ruhe (1954, 1969, 1983), Daniels and Handy (1959), Bettis (1990), and Forman et al. (1992), and all three are present at the Loveland paratype locality (Fig. 3). Tills that predate the penultimate glaciation underlie the lowest loess unit, which is called Loveland Loess and is thought to date from the penultimate ("Illinoian") glaciation. Thermoluminescence (TL) age estimates of Loveland 


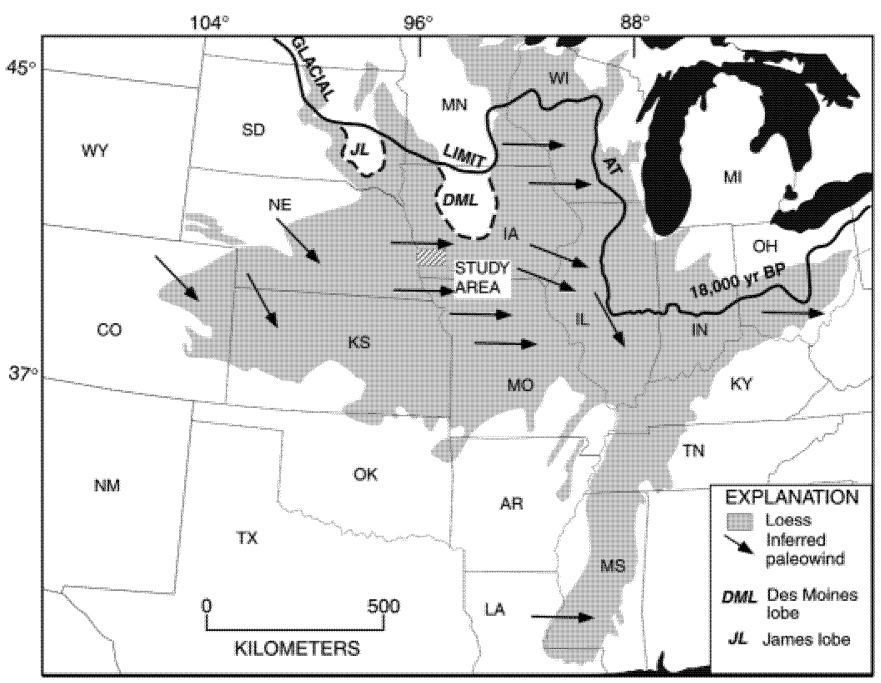

FIG. 1. Map showing distribution of late Pleistocene loess in the North American midcontinent, the study area in western Iowa, inferred paleowinds from loess data, and the approximate limit of the Laurentide ice sheet during the last glacial period. Arrows with solid heads indicate dominant wind directions interpreted from detailed loess thickness studies, particle-size data, and isotopic provenance studies. Arrows with open heads indicate wind directions of minor duration interpreted largely from thickness trends that occur over short $(\sim 25 \mathrm{~km})$ distances. Loess distribution slightly modified from Thorp and Smith (1952). Inferred dominant paleowinds taken from data in Smith (1942), Swineford and Frye (1951), Ruhe (1954), Fehrenbacher et al. (1965, 1986), Snowden and Priddy (1968), Frazee et al. (1970), Kleiss (1973), Rutledge et al. (1975), Ebens and Connor (1980), Putman et al. (1988), Hallberg et al. (1991), Whitfield et al. (1993), Swinehart et al. (1994), Leigh and Knox (1994), Mason et al. (1994), Rodbell et al. (1997), Muhs et al. 1999, and Aleinikoff et al. (1998, 1999). Inferred minor paleowinds taken from Fehrenbacher et al. (1965, 1986), Hallberg et al. (1991), Whitfield et al. (1993), and Swinehart et al. (1994).

Loess, ranging from $\sim 110,000$ to $\sim 165,000$ cal yr B.P., support this correlation (Forman et al., 1992) and are in good agreement with TL ages of Loveland Loess from Nebraska (Maat and Johnson, 1996). The last interglaciation is repre- sented by the Sangamon Geosol, which is developed in Loveland Loess. A thin loess unit called the Pisgah Formation (Bettis, 1990) overlies the Sangamon Geosol and is $\sim 4 \mathrm{~m}$ thick at the Loveland paratype locality. The Pisgah Formation has weak pedogenic alteration to the Farmdale Geosol, mainly in the form of organic matter accumulation, in the upper part of the unit. The Farmdale Geosol at Loveland resembles the Farmdale Geosol developed in Roxana Silt (loess) in the Mississippi River valley (McKay, 1979; Follmer, 1983). Radiocarbon ages ranging from $\sim 34,000$ (shell) to $\sim 31,000 \mathrm{yr}$ B.P. (disseminated organic matter) and TL ages of $\sim 30,000$ and $\sim 23,000$ cal yr B.P. (Forman et al., 1992) support a correlation of the Pisgah Formation with the Roxana Silt in Illinois (Curry and Follmer, 1992) and the Gilman Canyon Formation in Nebraska and Kansas (Martin, 1993; May and Holen, 1993; Maat and Johnson, 1996).

Peoria Loess occurs above the Pisgah Formation and is a light-brown, massive silt loam. At Loveland, Peoria Loess is as much as $41 \mathrm{~m}$ thick; radiocarbon ages of basal Peoria Loess are as old as $27,000-24,000{ }^{14} \mathrm{C}$ yr B.P. and TL ages are $22,000-$ 18,000 cal yr B.P. (Forman et al., 1992). In Harrison County, north of Loveland, Ruhe et al. (1971) reported a radiocarbon age of $\sim 22,000{ }^{14} \mathrm{C}$ yr B.P. for Peoria Loess $\sim 3.7 \mathrm{~m}$ above what we interpret to be the Pisgah Formation. Near the same locality, a sample $\sim 16.5 \mathrm{~m}$ above the base of Peoria Loess and $\sim 2.7 \mathrm{~m}$ below the top of it is $\sim 15,000{ }^{14} \mathrm{C}$ yr B.P. (Ruhe et al., 1971). In central Iowa, Peoria Loess is buried by a surficial till; spruce trees rooted in the loess have radiocarbon ages of $\sim 14,000{ }^{14} \mathrm{C}$ yr B.P. (Ruhe, 1969). In western Iowa, alluvium as old as $11,600-10,000{ }^{14} \mathrm{C}$ yr B.P. is not mantled by Peoria Loess (Daniels et al., 1963; Bettis, 1990). From all of these age estimates, we conclude that Peoria Loess deposition in western Iowa may have begun $\sim 27,000-24,000{ }^{14} \mathrm{C}$ yr B.P. Loess deposition could have ended as early as $14,000{ }^{14} \mathrm{C}$ yr B.P., but certainly ended before $\sim 11,000{ }^{14} \mathrm{C}$ yr B.P.

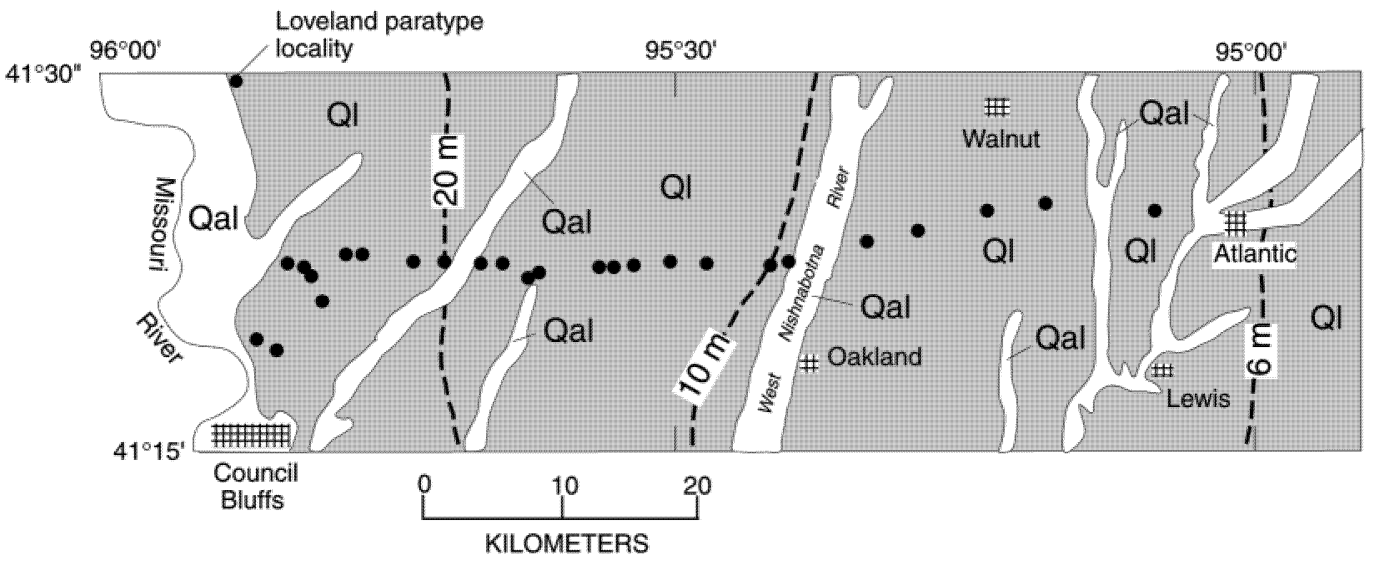

FIG. 2. Surficial geologic map of a part of southwestern Iowa, showing locations of the Loveland paratype section, loess transect samples (filled circles), and loess thickness contours in meters (from Hallberg et al., 1991). Surficial geology inferred from soil surveys of Jury et al. (1969) and Branham (1989), with field checking by the authors. Q1, loess; Qal, alluvium. 
a

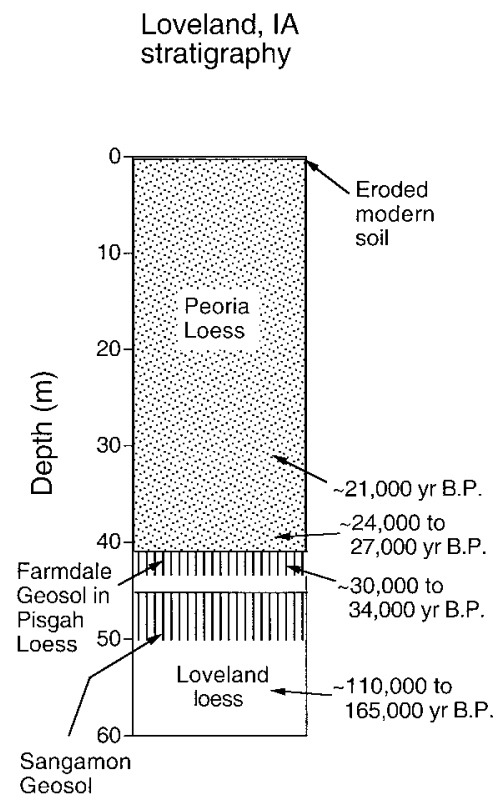

b

Fine silt $(2-20 \mu \mathrm{m})$
content $(\%)$

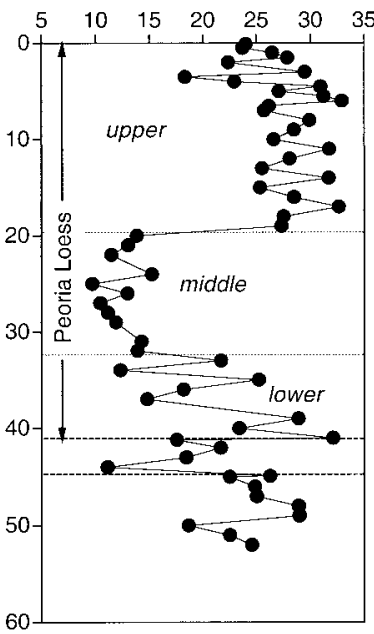

c

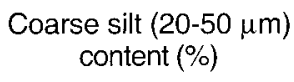
content $(\%)$

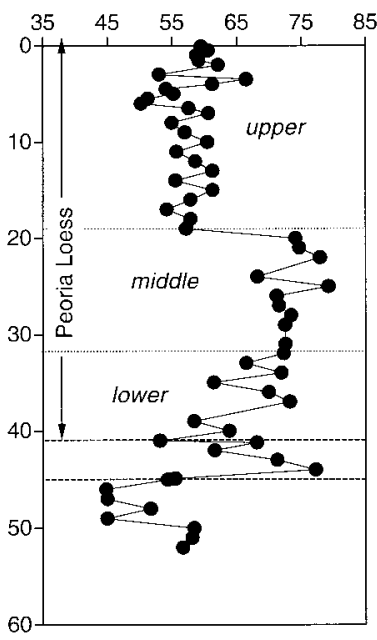

FIG. 3. Stratigraphy, generalized radiocarbon and thermoluminescence (TL) ages, and fine and coarse silt contents shown as a function of depth at the Loveland paratype locality. Particle sizes were determined by sieve (sand) and pipette (silt and clay) after removal of organic matter with $\mathrm{H}_{2} \mathrm{O}_{2}$, removal of carbonates with acetic acid, and dispersion with $\mathrm{Na}-$ hexametaphosphate. Age data were generalized from Forman et al. (1992).

\section{LOVELAND PARATYPE LOCALITY}

Detailed grain-size, geochemical, and mineralogical studies show that Peoria Loess at Loveland is not uniform with depth (Figs. 3-6). Coarse silt $(20-50 \mu \mathrm{m})$ is the modal particle-size fraction at all depths (Fig. 3), but there are significant differences within the section. Fine silt $(2-20 \mu \mathrm{m})$ shows three distinct zonations (informally termed "lower," "middle," and "upper"). The lower zone, between the contact with the Farmdale Geosol and a depth just below $\sim 30 \mathrm{~m}$, shows high variability, with fine silt values ranging from $\sim 12$ to $\sim 32 \%$. Above this is a middle zone of relatively low $(\sim 10-15 \%)$ amounts of fine silt up to a depth of $\sim 20 \mathrm{~m}$, in turn overlain by an upper zone of variable, but generally high $(\sim 22-34 \%)$ amounts of fine silt.

The contact between the lower zone of variable fine silt and the middle zone of low fine silt corresponds closely to the depth of the "deoxidized and leached" zone of Peoria Loess that has been identified in many western Iowa loess sections (Ruhe, 1969, 1983). Quartz/calcite and quartz/dolomite (and $\mathrm{SiO}_{2} / \mathrm{CaO}+\mathrm{MgO}$ ) values are similar in middle and upper Peoria Loess, but both are significantly lower than in lower Peoria Loess, indicating a much lower carbonate content in lower Peoria Loess (Fig. 4).

Both particle-size and chemical data show the boundary between middle and upper Peoria Loess. Upper Peoria Loess has a higher clay content than middle Peoria Loess (Fig. 5). Clay minerals, because of the composition of their octahedral layers, generally have higher $\mathrm{Al}_{2} \mathrm{O}_{3}$ and $\mathrm{Fe}_{2} \mathrm{O}_{3}$ contents compared to primary rock-forming aluminosilicates. The difference in clay content between the middle and upper Peoria zones is mirrored by their $\mathrm{Al}_{2} \mathrm{O}_{3}$ and $\mathrm{Fe}_{2} \mathrm{O}_{3}$ contents (Fig. 5).

The lower carbonate content in the lower Peoria Loess could be the result of either relatively low carbonate content in the source sediments or syndepositional leaching as a result of low sedimentation rates. Lower Peoria Loess in Kansas also has less carbonate compared to upper Peoria Loess, which was interpreted by Frye and Leonard (1952) to represent a period of low deposition rate and syndepositional carbonate leaching. Later work in Iowa and Illinois (Ruhe, 1969, 1983; Kleiss, 1973) and this study support this interpretation.

The difference in grain-size properties between the middle and upper Peoria Loess zones in Iowa can be interpreted as having either a paleoclimatic or a sediment source cause. The higher fine silt content in the upper Peoria could result from a shift in source sediment without a change in source location, greater relative input from more distant sources, and/or a change in wind strength. We favor the distant-source hypothesis and tested this in two ways.

The first test of the distant-source hypothesis is a comparison of the chemical composition of Peoria Loess at Loveland with Peoria Loess found to the west of Iowa (eastern Nebraska) and to the east of Iowa (western Illinois). We chose three loess sections in eastern Nebraska (Fig. 6): near Plattsmouth (a previously undescribed section), just north of Lincoln (Mandel 
Quartz/calcite

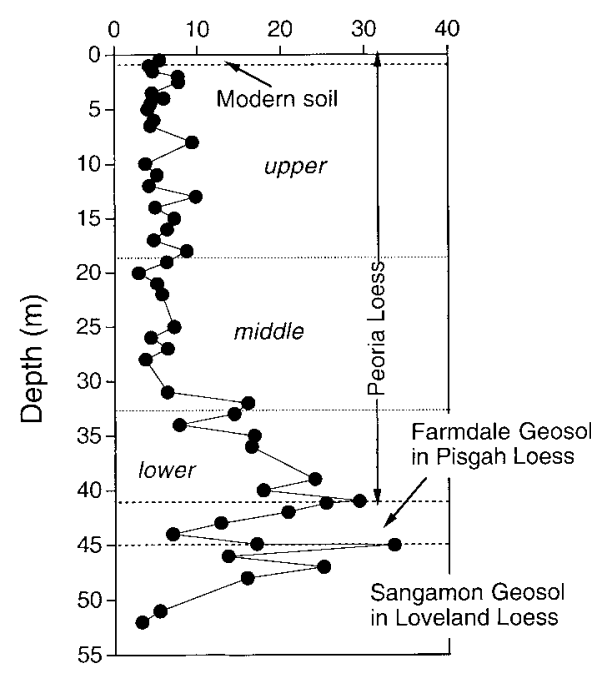

$\mathrm{SiO}_{2} / \mathrm{CaO}+\mathrm{MgO}$

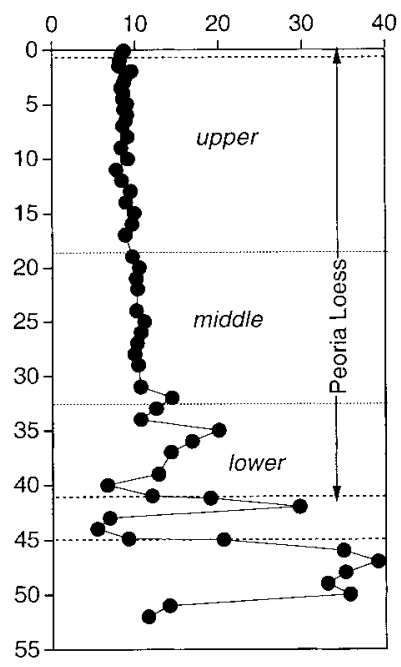

Quartz/dolomite

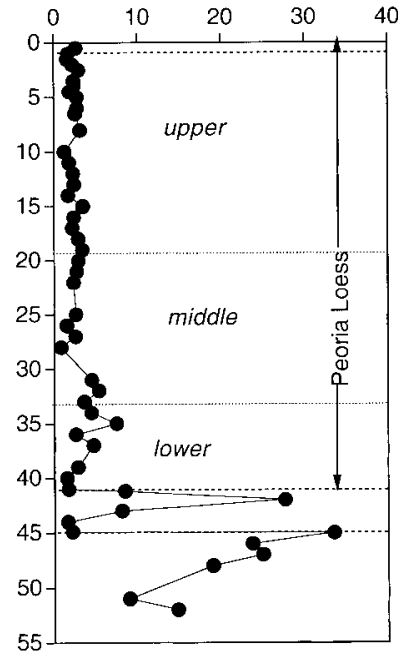

FIG. 4. Quartz/calcite, $\mathrm{SiO}_{2} / \mathrm{CaO}+\mathrm{MgO}$, and quartz/dolomite values in bulk (i.e., whole-sediment, without pretreatments) loess samples shown as a function of depth at the Loveland paratype locality. Mineral ratios are derived from the $20.8^{\circ} 2 \theta$ (quartz), $29.4^{\circ} 2 \theta$ (calcite), and $31.0^{\circ} 2 \theta$ (dolomite) X-ray diffraction peak heights; chemistry was done by wavelength-dispersive X-ray fluorescence.

and Bettis, 1995), and north of Elba (May et al., 1995). In Illinois, we sampled two previously described (Frye et al., 1968) sections, one at Morrison and another called "Rapids City B," just northeast of Moline (Fig. 6). New isotopic studies by Aleinikoff et al. (1998) suggest that much of the loess in Nebraska may be derived from a nonglaciogenic source and therefore should be chemically distinct from loess that has a glaciogenic origin, such as in Illinois (Frye et al., 1968;
McKay, 1979; Grimley et al., 1998). The chemical differences observed here support this interpretation. Western Illinois loess has higher $\mathrm{CaO}$ and $\mathrm{MgO}$ contents (from calcite and dolomite) than eastern Nebraska loess (Fig. 7). In contrast, Nebraska loess has higher $\mathrm{Fe}_{2} \mathrm{O}_{3}$ and $\mathrm{Al}_{2} \mathrm{O}_{3}$ contents (from clay minerals) than western Illinois loess. These differences largely reflect a carbonate dilution effect: higher carbonate contents in Illinois loess translate to relatively lower clay contents com-
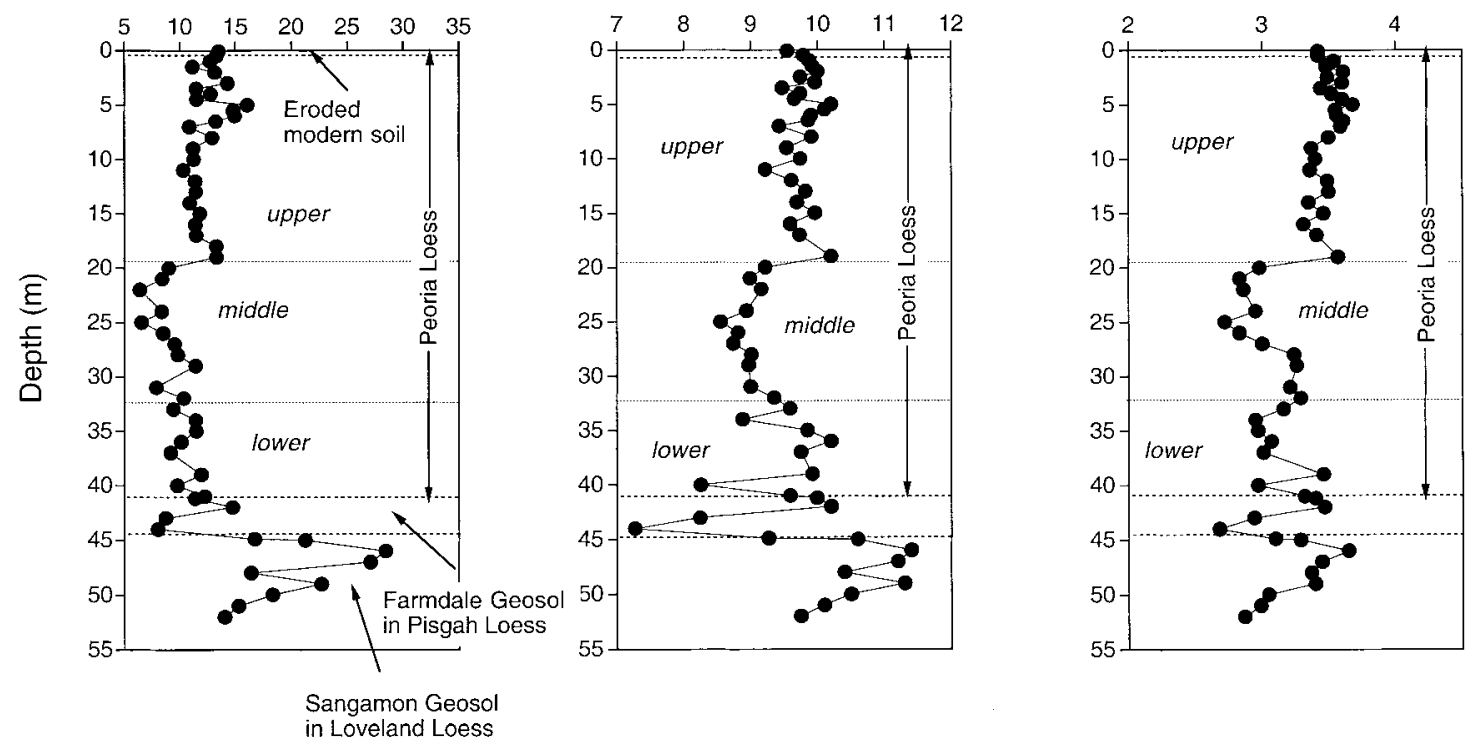

FIG. 5. Clay, $\mathrm{Al}_{2} \mathrm{O}_{3}$, and $\mathrm{Fe}_{2} \mathrm{O}_{3}$ contents from bulk loess samples shown as a function of depth at the Loveland paratype locality. 


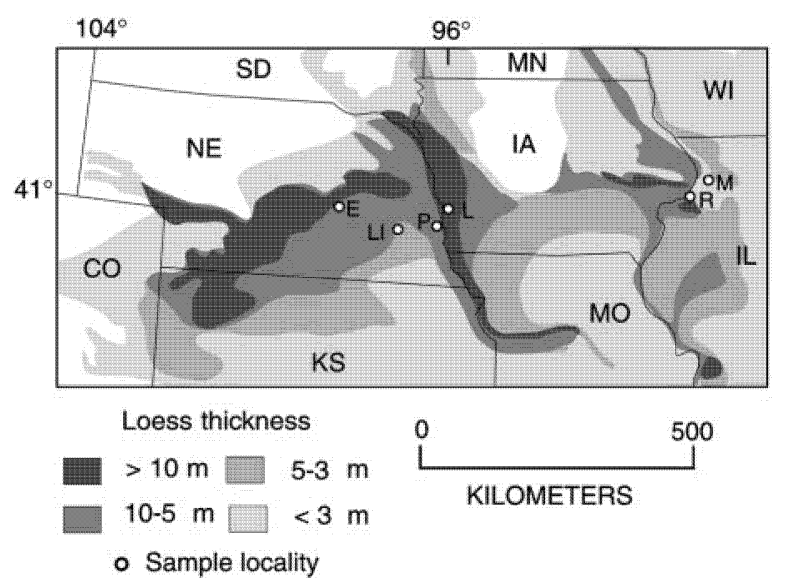

FIG. 6. Map showing loess distribution in Iowa and surrounding states and localities in Nebraska and Illinois where upper Peoria Loess was collected for geochemical analyses. Loess distribution from Lineback et al. (1983), Hallberg et al. (1991), Swinehart et al. (1994), and Muhs et al. (1999). L, Loveland paratype section; LI, Lincoln section; E, Elba section; P, Plattsmouth section; R, Rapids City B section; M, Morrison section.
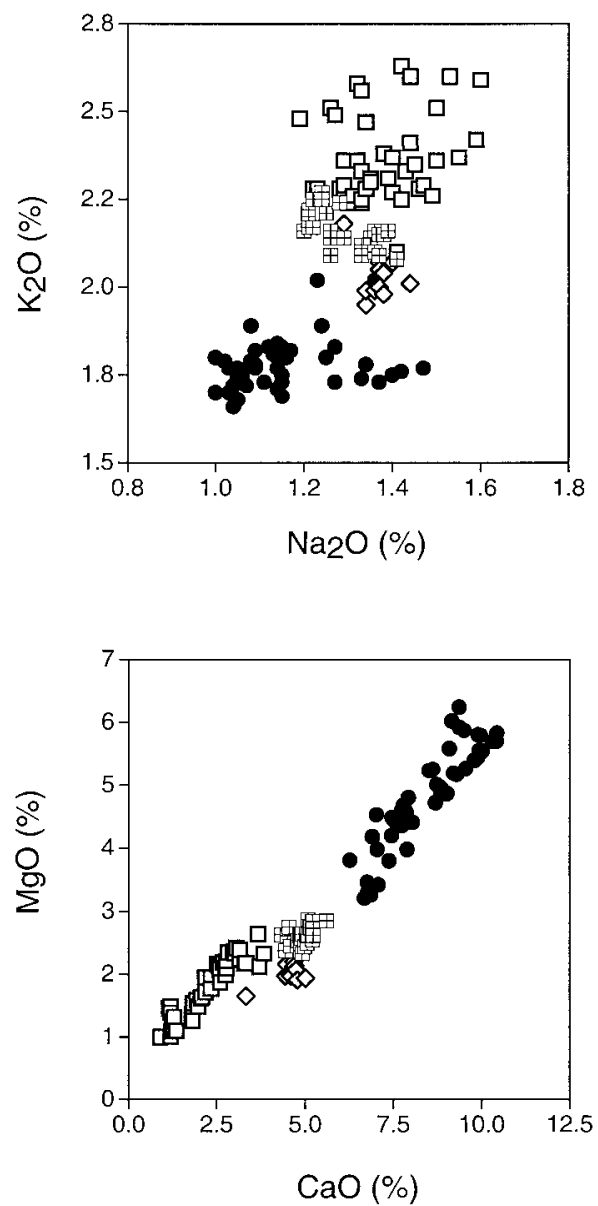

pared to Nebraska loess. However, Nebraska loess also has higher $\mathrm{K}_{2} \mathrm{O}$ content (K-feldspar and micas) and generally higher $\mathrm{Na}_{2} \mathrm{O}$ content (plagioclase), which suggest differences in silicate mineralogy unrelated to the carbonate dilution effect. Overall, Peoria Loess at Loveland has compositions that fall in between Nebraska and Illinois loess, indicating that it could contain a mixture of both Laurentide-derived source sediments and nonglaciogenic source sediments (Fig. 7). In addition, upper Peoria Loess at Loveland has $\mathrm{K}_{2} \mathrm{O}, \mathrm{Fe}_{2} \mathrm{O}_{3}$, and $\mathrm{Al}_{2} \mathrm{O}_{3}$ contents that are closer to values for Nebraska loess than are values for middle Peoria Loess at Loveland. This suggests that there may be a greater component of nonglaciogenic, Nebraska-type source sediments in upper Peoria Loess than in middle Peoria Loess at Loveland.

The second test of the distant-source hypothesis is an analysis of particle-size distribution in Nebraska loess. If the finer grained upper Peoria Loess at Loveland is the result of a downwind component of Nebraska loess being predominant over a Missouri River-derived source, then Peoria Loess at a locality near Loveland (but west of the Missouri River) should have a particle-size distribution that is similar to that of upper

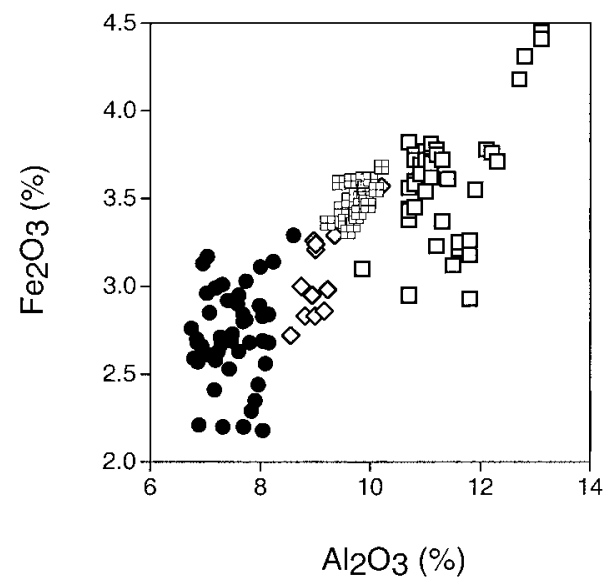

$\mathrm{Al}_{2} \mathrm{O}_{3}(\%)$

\section{.}

\section{.}


Peoria Loess at Loveland. The Plattsmouth and Elba sections, described above, meet these requirements. Fine silt $(2-20 \mu \mathrm{m})$ content in Peoria Loess at Plattsmouth is variable, but overall very high, never less than $20 \%$, and sometimes more than $35 \%$ (Fig. 8). These values are similar to, or higher than, fine silt values of upper Peoria Loess at Loveland and much higher than those in middle Peoria Loess at Loveland. At Elba, fine silt content in Peoria loess ranges from 20 to $25 \%$ (Fig. 9).

In eastern Nebraska, there is a 15 - to $25-\mathrm{km}$-wide zone of westward-thinning loess (Hallberg et al., 1991; Swinehart et al., 1994). It is difficult to explain this thickness trend other than by derivation from occasional eastward winds transporting loess from a Missouri River valley source (Handy, 1976). Plattsmouth is within this narrow zone of westward-thinning loess, and therefore it could be argued that the higher fine silt content there is a function of relatively weak easterly winds from a Missouri River valley source. However, Elba is $\sim 185$ $\mathrm{km}$ west of the Missouri River (Fig. 6), well west of this narrow zone of westward-thinning loess, and yet has a fine silt content similar to that at Plattsmouth. We conclude that Peoria loess in Nebraska has, overall, a relatively high content of fine silt and that the upper Peoria loess at Loveland contains a component of Nebraska-derived loess.

\section{UPPER PEORIA LOESS TRANSECT IN WESTERN IOWA}

Early studies by Hutton (1947) and Simonson and Hutton (1954) demonstrated that loess thins systematically away from the Missouri River in western Iowa. Ruhe (1954) measured loess thickness from railroad cuts in western Iowa and showed how both lower Peoria Loess and middle-plus-upper Peoria Loess (our terminology) thin to the east of the Missouri River bluffline. Ruhe's study did not include any thick loess deposits found immediately to the east of the Missouri River valley. Adding Loveland section thickness data to Ruhe's strengthens the correlation coefficients for loess thickness with distance east of the Missouri River bluffline (Fig. 10a). This supports an interpretation that the Missouri River valley was an important source of both lower and upper + middle Peoria Loess.

In addition to eastward thinning of loess deposits, certain grain-size properties of loess show very high correlations with distance from river valleys that are thought to be their main sources (Smith, 1942). Some of these trends, including decreases in coarse and medium silt and increases in fine silt and clay, are considered to be the result of downwind winnowing of coarse particles (Ruhe, 1954). In order to test these inferences further, we conducted major and trace element geochemical analyses of loess in an east-west transect (Fig. 2) using many of the same localities studied by Ruhe (1954), but also with several new localities closer to the bluffline. All samples were taken well below the modern soil zone, generally at depths of 2-3 m, and therefore represent unweathered upper Peoria Loess.

In western Iowa, clay content of loess increases to the east
(Ruhe, 1954). This observation is interpreted to be the result of winnowing of coarse particles in a downwind direction. Because the clay fraction of loess is dominated by phyllosilicate clay minerals rather than clay-sized primary minerals such as quartz and feldspars, it is expected that an eastward increase in clay mineral content should be reflected in major elements (such as $\mathrm{Al}$ and $\mathrm{Fe}$ ) that are concentrated in phyllosilicates. $\mathrm{Al}_{2} \mathrm{O}_{3}$ and $\mathrm{Fe}_{2} \mathrm{O}_{3}$ contents show increases to the east, with a high correlation with log-transformed distance for $\mathrm{Al}_{2} \mathrm{O}_{3}\left(r^{2}=\right.$ $0.70)$ and a lower $\left(r^{2}=0.50\right)$ but still highly significant correlation for $\mathrm{Fe}_{2} \mathrm{O}_{3}$ (Figs. 10b and 10c).

Pioneering work on the geochemistry of loess by workers in Illinois identified silt-size fractions where certain elements are concentrated. Beavers et al. (1963) and Jones et al. (1967) found that $\mathrm{Zr}$ has the highest concentrations in coarse silt $(50-20 \mu \mathrm{m})$, whereas $\mathrm{Ti}$ and $\mathrm{K}$ have the highest concentrations in fine silt $(20-2 \mu \mathrm{m})$, when size fractions are separated by sedimentation. Therefore, it is expected that $\mathrm{Zr}$ concentrations ought to decrease away from a source whereas $\mathrm{K}$ and $\mathrm{Ti}$ concentrations should increase away from a source. In western Iowa, geochemical data for silt-related elements support the expected trends. Concentrations of $\mathrm{K}_{2} \mathrm{O}$ show an eastward increase with a relatively high $\left(r^{2}=0.61\right)$ degree of explanation; $\mathrm{Rb}$, a trace element that follows $\mathrm{K}$, shows a similar trend with a moderate $\left(r^{2}=0.51\right)$ degree of explanation (Fig. 11). Concentrations of $\mathrm{TiO}_{2}$ also show eastward increases with a high $\left(r^{2}=0.70\right)$ correlation, whereas $\mathrm{Zr}$ shows decreased concentrations to the east (Fig. 11). Collectively, the siltrelated elements suggest paleowinds from the west.

Carbonate content in loess was reported by Smith (1942) to decrease away from source areas in Illinois. His interpretation of this trend is that, farther from the source, deposition rates are low enough that carbonate leaching can keep pace with loess accumulation. Ruhe (1954) reported an increase in carbonate content with distance east of the Missouri River and attributed this to a secondary concentration at depth. In the present study, both $\mathrm{CaO}$ and $\mathrm{Sr}$ (a trace element that follows $\mathrm{Ca}$ ) show eastward decreases with moderate but significant correlations (Fig. 12). In the same transect, $\mathrm{MgO}$ also shows an eastward decrease, but the correlation is not nearly as high $\left(r^{2}=0.35\right)$ as for $\mathrm{CaO}$ and $\mathrm{Sr}$. Although $\mathrm{Mg}$ substitutes for $\mathrm{Ca}$ in calcite $\left[\mathrm{CaCO}_{3}\right]$, it is a more important element in dolomite $\left[\mathrm{CaMg}\left(\mathrm{CO}_{3}\right)_{2}\right]$. Because dolomite is not as soluble as calcite, a correlation as high as that for $\mathrm{CaO}$ would not be expected. We have no explanation for the difference between Ruhe's (1954) carbonate content results and ours; geochemical trends reported here support syndepositional weathering during loess accumulation that is consistent with what Smith (1942) reported for Illinois.

The east-west transect trends for both clay-related and carbonate-related elements in western Iowa are in good agreement with the only other loess geochemistry study of which we are aware for the Missouri River basin. Ebens and Connor (1980) studied changes in loess geochemistry in northwest Missouri in 

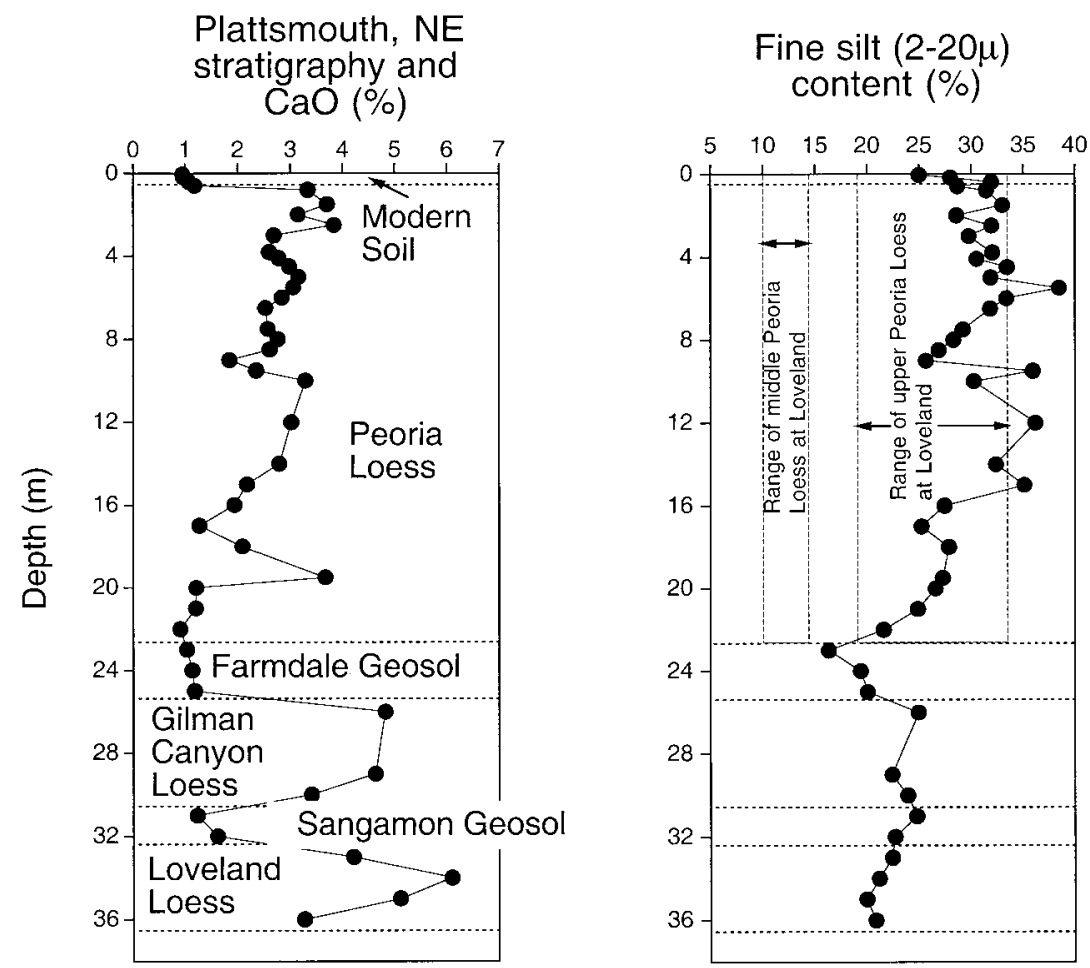
Coarse silt $(20-50 \mu)$ content $(\%)$

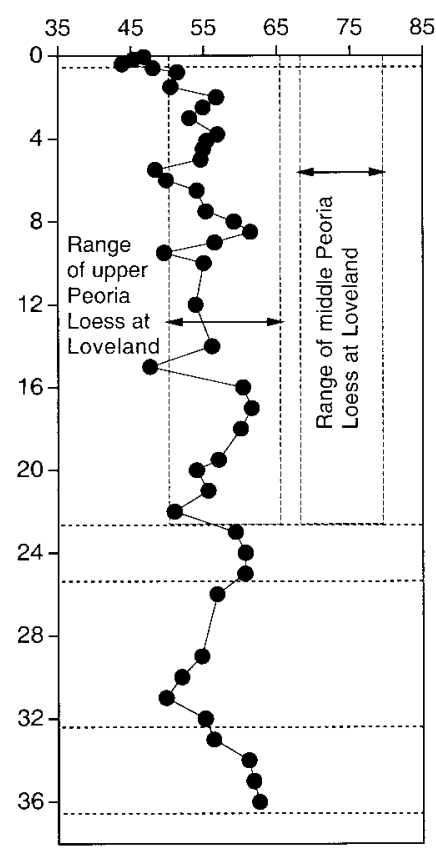

FIG. 8. Stratigraphy, $\mathrm{CaO}$ content, and fine and coarse silt contents shown as a function of depth at the Plattsmouth, Nebraska locality.

three east-west transects east of the Missouri River (Fig. 1). They also found that $\mathrm{Al}_{2} \mathrm{O}_{3}$ and $\mathrm{Fe}_{2} \mathrm{O}_{3}$ contents increased and $\mathrm{CaO}$ and $\mathrm{MgO}$ contents decreased eastward from the Missouri River. In addition, the geochemical trends for western Iowa are similar to those from China (Eden et al., 1994), where loess source areas are considered to be desert areas found to the north and northwest of the Loess Plateau (Zhang et al., 1999). Eden et al. (1994) found that $\mathrm{MgO}$ contents decrease from north to south across the Loess Plateau, whereas $\mathrm{K}_{2} \mathrm{O}, \mathrm{TiO}_{2}, \mathrm{Al}_{2} \mathrm{O}_{3}$, and $\mathrm{Fe}_{2} \mathrm{O}_{3}$ all show increases from north to south.
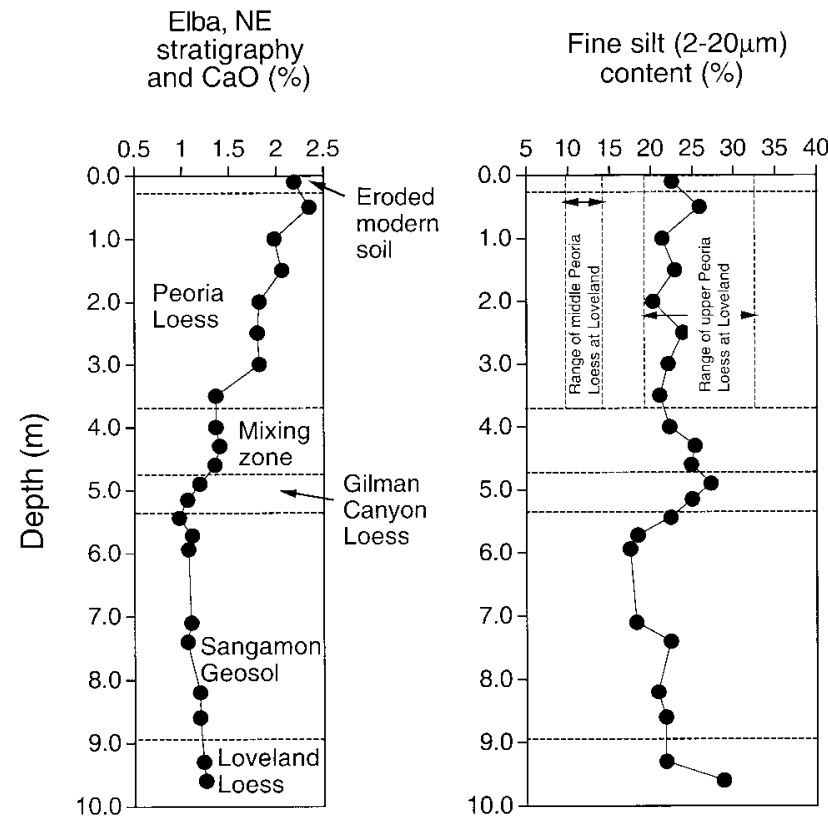

\section{Coarse silt $(20-50 \mu \mathrm{m})$ content $(\%)$}

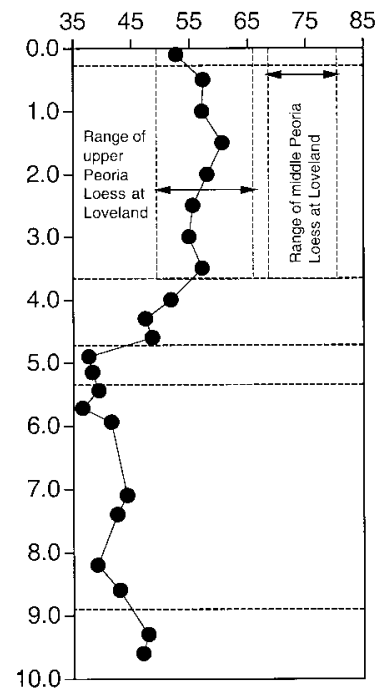

FIG. 9. Stratigraphy, $\mathrm{CaO}$ content, and fine and coarse silt contents shown as a function of depth at the Elba, Nebraska locality. 


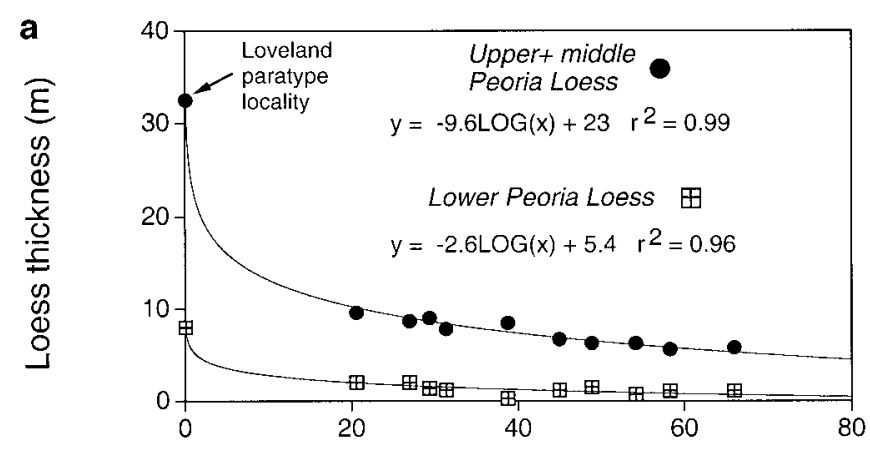

Distance east of the Missouri River bluffline $(\mathrm{km})$

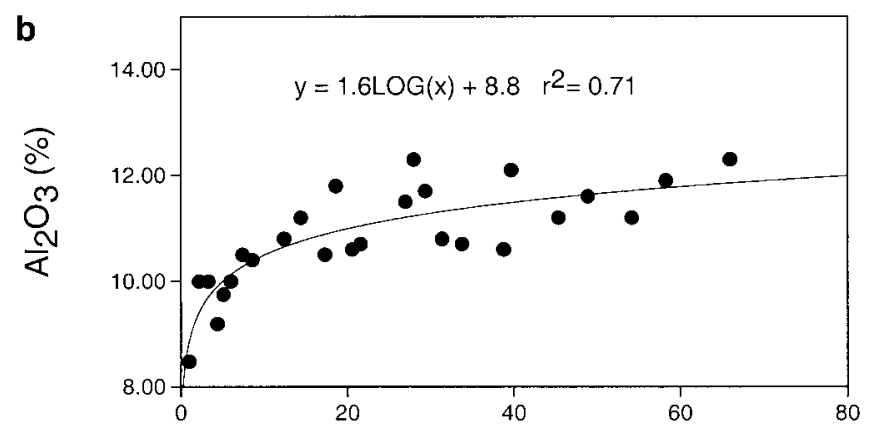

Distance east of the Missouri River bluffline $(\mathrm{km})$

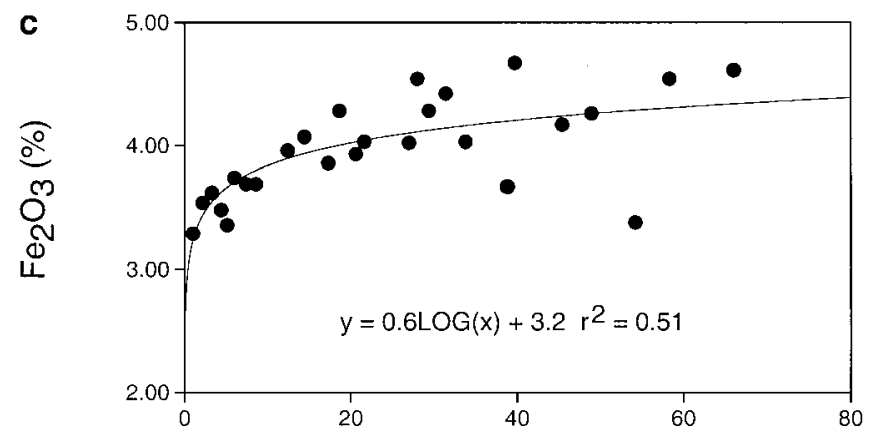

Distance east of the Missouri River bluffline $(\mathrm{km})$

FIG. 10. (a) Thickness of the upper-plus-middle Peoria Loess and lower ("leached") Peoria Loess in western Iowa as a function of distance east of the Missouri River bluffline. Derived from stratigraphic data given in Ruhe (1983), except for the Loveland paratype locality, which is from this study. (b) and (c) Concentrations of $\mathrm{Al}_{2} \mathrm{O}_{3}$ and $\mathrm{Fe}_{2} \mathrm{O}_{3}$ in bulk samples of loess shown as a function of distance east of the Missouri River bluffline.

\section{DISCUSSION}

The data from the Loveland paratype locality and the eastwest transect data support the interpretation that paleowinds that deposited lower, middle, and upper Peoria Loess were all from the west, or at least had a strong westerly component, in agreement with previous loess studies in western Iowa (Hutton,
1947; Simonson and Hutton, 1954; Ruhe, 1954, 1969, 1983; Hallberg, 1979). These results are also in agreement with a compilation of published loess studies from the midcontinent that have been conducted over the past several decades. For this compilation, we chose those localities where detailed field studies of loess thickness were conducted (e.g., Fehrenbacher et al., 1965, 1986), detailed particle-size analyses were made (e.g., Smith, 1942), or detailed thickness studies can be combined with provenance studies using isotopes (e.g., Swinehart et al., 1994, along with Aleinikoff et al., 1998). Results indicate that south of the Laurentide ice sheet, from Colorado to Ohio, winds over the North American midcontinent were dominantly from the west or northwest during loess transport (Fig. 1). It is important to note that results of this compilation largely reflect the sampling scheme of the individual studies. For example, had an investigator chosen a northwest-to-southeast sampling design rather than a west-to-east one, results could still yield a high correlation, but an interpretation might be made for a "northwesterly" rather than a "westerly" paleowind. Hence, our overall interpretation of the compilation shown in Figure 1 is that winds had at least some westerly component, but it is possible the dominant winds were westerly, northwesterly, or even southwesterly. Furthermore, it is important to emphasize that winds shown as northwesterly in one area near winds shown as westerly do not necessarily reflect local variation; more likely, they simply reflect the sampling design of the original investigators.

A few areas show differences from the overall westerly paleowind that seems to be characteristic of the region. Thickness data reported by Fehrenbacher et al. $(1965,1986)$ for areas west of the Wabash and Illinois Rivers in Illinois and those reported by Hallberg et al. (1991), Whitfield et al. (1993), and Swinehart et al. (1994) for areas west of the Missouri River in Nebraska and Kansas show decreases to the west (Fig. 1). Fehrenbacher et al. (1965) interpreted the decreasing loess thickness to the west of the Wabash River in Illinois to be the result of deposition from easterly winds, although their overall conclusion was that west and northwest winds were the most important paleowinds over most of the Mississippi River valley region. They suggested that loess deposition in southern Illinois and Indiana was probably the result of cyclonic and anticyclonic circulation, as well as katabatic winds off the Laurentide ice sheet.

In one of the most comprehensive comparisons of LGM paleoclimate data and a simulated LGM paleoclimate derived from an atmospheric general circulation model, COHMAP members (1988) concluded that the Laurentide ice sheet generated a strong glacial anticyclone over the interior of North America (Fig. 13). Hobbs (1943) was perhaps the first to hypothesize the existence of such a feature over the Laurentide ice sheet and attempted to explain loess distribution in North America as a function of anticyclonic circulation. According to the COHMAP (1988) reconstruction, winds generated from this high pressure cell would have been easterly or northeast- 


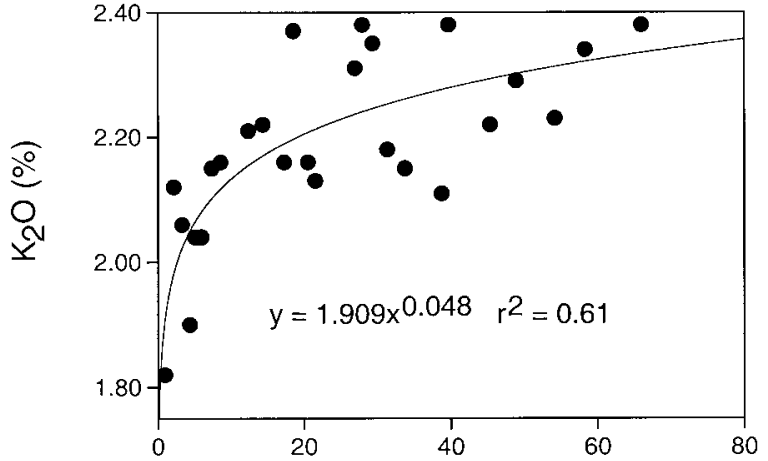

Distance east of the Missouri River bluffline $(\mathrm{km})$

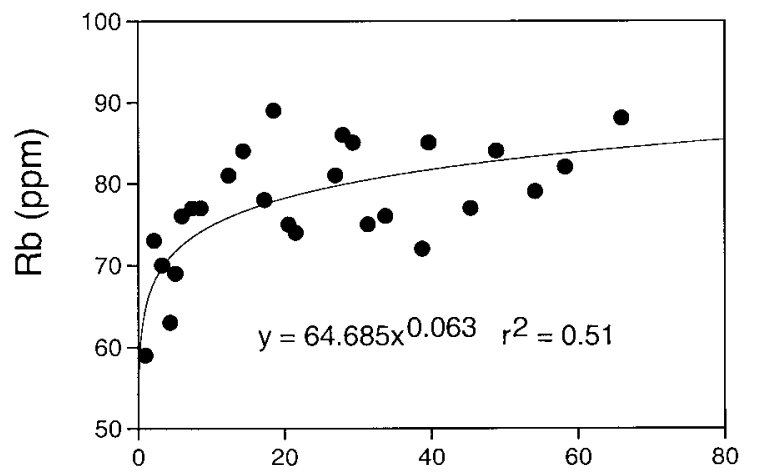

Distance east of the Missouri River bluffline $(\mathrm{km})$

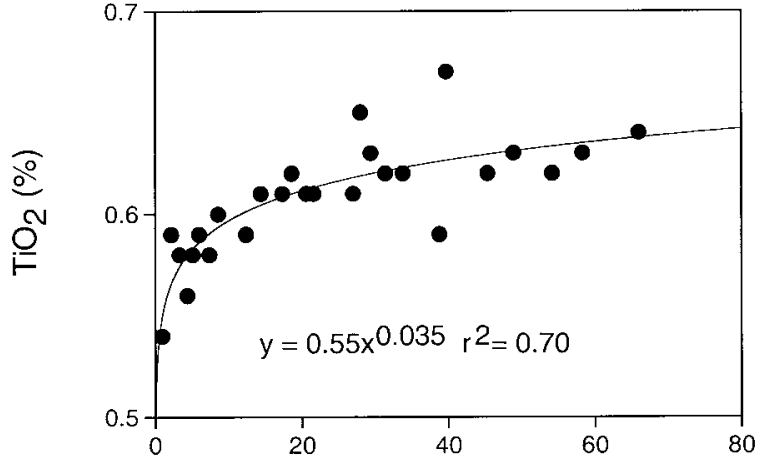

Distance east of the Missouri River bluffline $(\mathrm{km})$

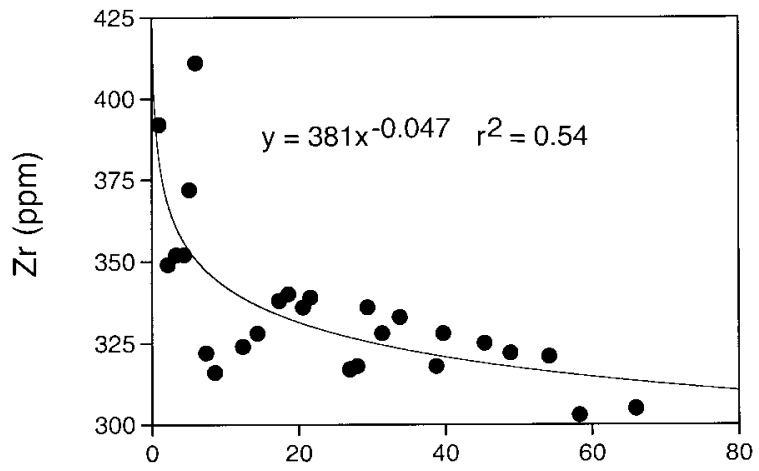

Distance east of the Missouri River bluffline $(\mathrm{km})$

FIG. 11. Concentrations of $\mathrm{K}_{2} \mathrm{O}, \mathrm{Rb}, \mathrm{TiO}_{2}$, and $\mathrm{Zr}$ in bulk samples of loess shown as a function of distance east of the Missouri River bluffline.

erly to the south of the ice sheet, including Iowa and other areas in the midcontinent. The contrast between what we call dominant loess-derived paleowinds and AGCM-generated paleowinds under a glacial anticyclone is striking (Fig. 13) and requires discussion.

At least five explanations for the disparity between loessderived paleowinds and AGCM paleowinds are possible.

1. Loess was not being deposited at $\sim 21,000$ cal yr B.P. ( 18,000 ${ }^{14} \mathrm{C}$ yr B.P.). Both radiocarbon and TL dating from a number of localities clearly indicate that this explanation is not correct. At most localities, loess deposition began around $22,000-20,000{ }^{14} \mathrm{C}$ yr B.P. and ended about $14,000-12,000$ ${ }^{14}$ C yr B.P. (Follmer, 1983; Forman et al., 1992; Grimley et al., 1998; Maat and Johnson, 1996; Mandel and Bettis, 1995; McKay, 1979; Muhs et al., 1999; Rodbell et al., 1997; Ruhe, 1969; Ruhe et al., 1971), a time interval that brackets the LGM.

2. Loess was deposited in a season when there was no glacial anticyclone. COHMAP members (1988, p. 1052, note 42) recognized the disparity between their model and interpretation of loess-derived paleowinds and suggested that the northwesterly winds which transported loess were a seasonal phenomenon. Because the latest AGCM simulations in- dicate the presence of a LGM glacial anticyclone in both winter and summer (Kutzbach et al., 1998; Bartlein et al., 1998), seasonal differences in wind regime cannot reconcile the model results with the loess-derived paleowinds.

3. The glacial anticyclone, as reported by COHMAP members (1988), is incorrectly simulated. This explanation seems unlikely, because virtually all AGCMs that have modeled the LGM have produced a glacial anticyclone over the Laurentide ice sheet. For example, in addition to COHMAP, Broccoli and Manabe (1987) also produced a glacial anticyclone over the Laurentide ice sheet in their AGCM, although they reported northwesterly winds immediately to the south of the ice sheet in winter, and less vigorous circulation, with only minor alterations from control experiments, in summer. Importantly, different AGCM experiments by the COHMAP group with a reduced ice sheet height and lower $\mathrm{CO}_{2}$ values did not produce significantly different results from the 1988 study (Kutzbach et al., 1993). This conclusion is also supported by new experiments with the later (CCM1) version of this AGCM, where the glacial anticyclone is not as well developed as in an earlier (CCM0) version, but is still apparent in both summer and winter at the LGM (Kutzbach et al., 1998; Bartlein et al., 


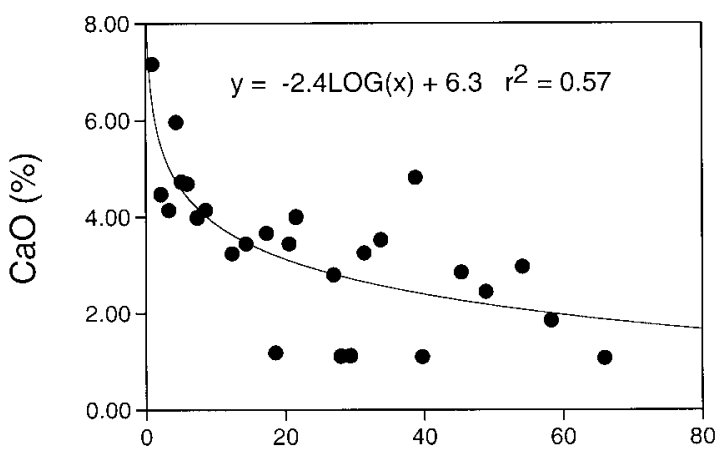

Distance east of the Missouri River bluffline $(\mathrm{km})$

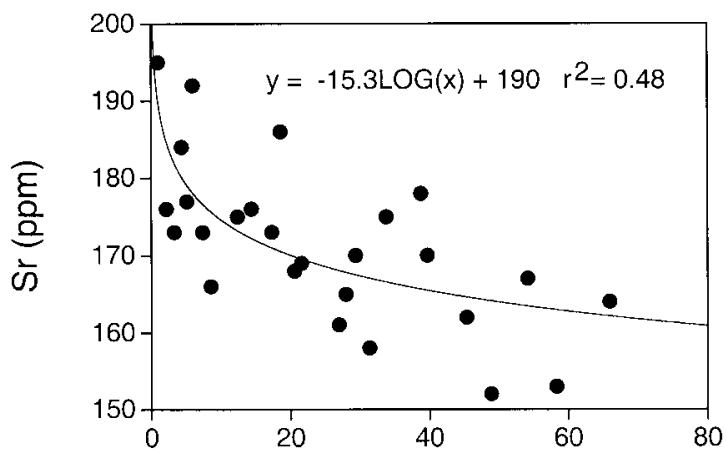

Distance east of the Missouri River bluffline $(\mathrm{km})$

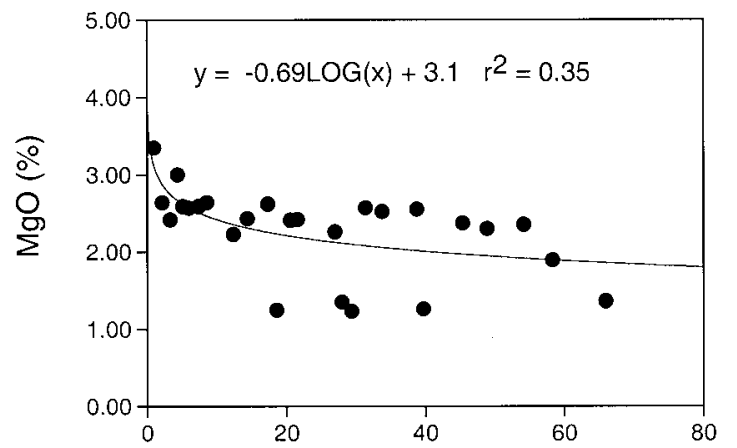

Distance east of the Missouri River bluffline (km)

FIG. 12. Concentrations of $\mathrm{CaO}, \mathrm{MgO}$, and $\mathrm{Sr}$ in bulk samples of loess shown as a function of distance east of the Missouri River bluffline.

1998). The presence of the glacial anticyclone in several AGCMs, with different boundary conditions, suggests that it is a robust feature of circulation during full-glacial time.

4. Northeasterly winds were limited to the ice sheet itself or to a very narrow band to the south of it. It is unlikely that northeasterly winds were limited to the area over the ice sheet, because it is the pressure gradient from the air mass over the ice sheet itself and the region to the south of it (as modified by
Coriolis force) that creates northeasterly surface winds. The locations of many loess transects with westerly or northwesterly winds very close to the Laurentide ice sheet (Fig. 1), as well as significantly to the south of it, suggest that this was a dominant wind pattern over the entire region.

5. Northwesterly winds, which transported the loess, were high-velocity but low-frequency events. Although the COHMAP model simulated northeasterly winds to the south of the ice sheet as a general condition during the LGM, it is possible that infrequent northwesterly winds, unrelated to the glacial anticyclone, were responsible for most loess transport. It is important to note that surface winds generated by the glacial anticyclone (as simulated by AGCMs) are relatively weak (e.g., Kutzbach et al., 1998, Fig. 3a). These weak winds may explain the few transects that show loess thickness decreases over short $(\sim 25 \mathrm{~km})$ distances to the west of the Wabash, Illinois, and Missouri rivers. However, another feature of COHMAP model simulations is southward displacement of the jet stream from its present position during the LGM, due to the presence of the ice sheet. The trajectories of these upper-air winds are good indicators of the general position of storm tracks. Although the jet stream during the LGM, as generally modeled by COHMAP, would have been located well to the south of most areas of loess deposition, it is possible that infrequent shifts of the jet to the north would have brought

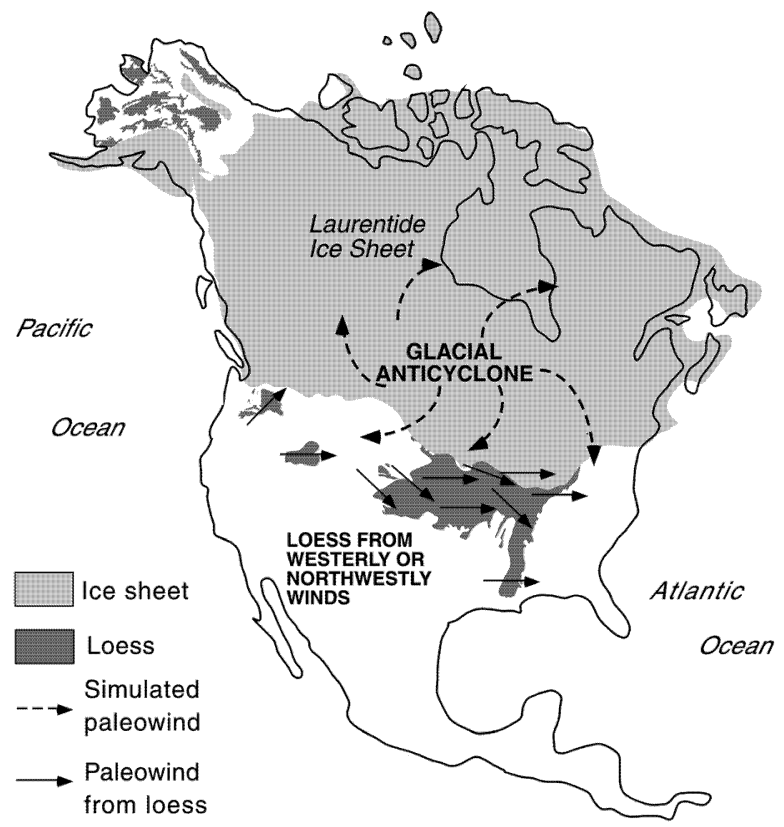

FIG. 13. Map of North America showing extent of the Laurentide ice sheet at the last glacial maximum and wind patterns derived from a modeled glacial anticyclone (COHMAP Members, 1988) compared to those derived from loess distributions. Extent of last-glacial loess from Thorp and Smith (1952) and Péwé (1975); loess paleowinds from references in Figure 1 legend, Lewis et al. (1975), Lewis and Fosberg (1982), Pierce et al. (1983), and Busacca and McDonald (1994). 
storm tracks (and with them, high-velocity winds) that were capable of transporting silt. A modern example of such a process might be the low-pressure system that passed over the Great Plains in February 1977 (McCauley et al., 1981). The strong (up to $145 \mathrm{~km} / \mathrm{h}$ ) winds that accompanied this lowpressure system generated large dust storms (to heights of up to $4000 \mathrm{~m}$ ) in eastern Colorado and parts of the Southern High Plains. A factor that was critical to the generation of the large dust storms was a long, dry period previous to the passage of the low pressure system. AGCMs simulate relatively dry conditions to the south of the Laurentide ice sheet during the LGM (Kutzbach et al., 1998; Bartlein et al., 1998). Such conditions, combined with abundant sediment supplies in major valley trains, could have "set the stage" for large-scale dust entrainment during periods when infrequent, but strong, low-pressure systems passed through the region.

\section{CONCLUSIONS}

Thick Peoria Loess at the Loveland paratype locality in western Iowa does not have a uniform chemical composition or particle-size distribution; three zones are recognized: lower, middle, and upper. Lower Peoria Loess accumulated slowly with syndepositional carbonate leaching. The middle Peoria Loess zone is characterized by relatively high carbonate content and abundant coarse silt and probably represents higher rates of loess accumulation. The upper Peoria Loess zone is also calcareous and accumulated rapidly, but is finer grained than middle Peoria Loess. Middle and upper Peoria Loess in western Iowa have chemical characteristics intermediate between loess in western Illinois and eastern Nebraska, but are closest to that in eastern Nebraska. Peoria Loess in western Iowa is therefore interpreted to have had at least two sources: the Missouri River valley, and an additional source which lay to the west of the Missouri River valley. Particle-size data suggest that, during deposition of middle Peoria Loess, the Missouri River valley source was dominant, but during deposition of upper Peoria Loess, the western source was dominant. During both periods of loess deposition, therefore, winds were westerly or had a westerly component. This interpretation is supported by geochemical variations in upper Peoria Loess in an east-west transect sampled to the east of the Missouri River in western Iowa.

A compilation of LGM paleowinds derived from loess studies in Iowa and elsewhere in the midcontinent indicates that westerly or northwesterly winds were dominant during loess transport over much of the region south of the Laurentide ice sheet. Westerly or northwesterly winds during the LGM are not in agreement with paleowinds simulated by AGCMs. Most models produce a strong glacial anticyclone over the Laurentide ice sheet, and this would have generated easterly or northeasterly winds during LGM summers. The reason for the discrepancy between the AGCM reconstruction of paleowinds and the loess record is not understood. A possible explanation is that loess deposition may be a function of infrequent but strong northwesterly winds generated by low-pressure systems associated with the jet stream and unrelated to winds generated by the glacial anticyclone.

\section{ACKNOWLEDGMENTS}

This study was supported jointly by the Iowa Department of Natural Resources-Geological Survey Bureau and the Earth Surface Dynamics Program of the U.S. Geological Survey. Vern Souders introduced us to the Elba loess section. We thank the landowners at Morrison (Pauline Meakins) and Rapids City (Dan Van Besien) for access to their property. Robert and Dorothea Muhs provided logistical support during field work. Josh Been, Scott Cowherd, and Shannon Mahan assisted with laboratory work. We appreciate helpful discussions of climate models with Pat Bartlein and Tony Broccoli. Joseph Mason, Leon Follmer, John Aleinikoff, Ralph Shroba, and Ken Pierce provided constructive comments on an earlier version of the paper.

\section{REFERENCES}

Aleinikoff, J. N., Muhs, D. R., and Fanning, C. M. (1998). Isotopic evidence for the sources of late Wisconsin (Peoria) loess, Colorado and Nebraska: Implications for paleoclimate. In "Dust Aerosols, Loess Soils and Global Change" (A. J. Busacca, Ed.), pp. 124-127. Washington State Univ. College of Agriculture and Home Economics, Miscellaneous Publication No. MISC0190, Pullman, WA.

Aleinikoff, J. N., Muhs, D. R., Sauer, R., and Fanning, C. M. (1999). Late Quaternary loess in northeastern Colorado, II. Pb isotopic evidence for the variability of loess sources. Geological Society of America Bulletin 111, 1876-1883.

Bartlein, P. J., Anderson, K. H., Anderson, P. M., Edwards, M. E., Mock, C. J., Thompson, R. S., Webb, R. S., Webb, T., III, and Whitlock, C. (1998). Paleoclimate simulations for North America over the past 21,000 years: Features of the simulated climate and comparisons with paleoenvironmental data. Quaternary Science Reviews 17, 549-585.

Beavers, A. H., Fehrenbacher, J. B., Johnson, P. R., and Jones, R. L. (1963). $\mathrm{CaO}-\mathrm{ZrO}_{2}$ molar ratios as an index of weathering. Soil Science Society of America Proceedings 27, 408-412.

Bettis, E. A., III. (1990). "Holocene Alluvial Stratigraphy and Selected Aspects of the Quaternary History of Western Iowa." Midwest Friends of the Pleistocene, 37th Field Conference Guidebook.

Branham, C. E. (1989). "Soil Survey of Pottawattamie County, Iowa." U.S. Department of Agriculture, Soil Conservation Service, U. S. Government Printing Office, Washington, DC.

Broccoli, A. J., and Manabe, S. (1987). The effects of the Laurentide ice sheet on North American climate during the last glacial maximum. Géographie Physique et Quaternaire 41, 291-299.

Busacca, A. J., and McDonald, E. V. (1994). Regional sedimentation of late Quaternary loess on the Columbia Plateau: Sediment source areas and loess distribution patterns. Washington Division of Geology and Earth Resources Bulletin 80, 181-190.

COHMAP Members (1988). Climatic changes of the last 18,000 years: Observations and model simulations. Science 241, 1043-1052.

Curry, B. B., and Follmer, L. R. (1992). The last interglacial-glacial transition in Illinois: 123-25 ka. In "The Last Interglacial-Glacial Transition in North America" (P. U. Clark and P. D. Clark, Eds.). Geological Society of America Special Paper 270, 71-88.

Daniels, R. B., and Handy, R. L. (1959). Suggested new type section for the Loveland loess in western Iowa. Journal of Geology 67, 114-119. 
Daniels, R. B., Rubin, M., and Simonson, G. H. (1963). Alluvial chronology of the Thompson Creek watershed, Harrison County, Iowa. American Journal of Science 261, 473-487.

Ebens, R. J., and Connor, J. J. (1980). "Geochemistry of loess and carbonate residuum." U.S. Geological Survey Professional Paper 954-G.

Eden, D. N., Qizhong, W., Hunt, J. L., and Whitton, J. S. (1994). Mineralogical and geochemical trends across the Loess Plateau, North China. Catena 21, 73-90.

Fehrenbacher, J. B., Olson, K. R., and Jansen, I. J. (1986). Loess thickness in Illinois. Soil Science 141, 423-431.

Fehrenbacher, J. B., White, J. L., Ulrich, H. P., and Odell, R. T. (1965). Loess distribution in southeastern Illinois and southwestern Indiana. Soil Science Society of America Proceedings 29, 566-572.

Follmer, L. R. (1983). Sangamon and Wisconsinan pedogenesis in the Midwestern United States. In "Late Quaternary Environments of the United States: Volume 1, The Late Pleistocene" (H. E. Wright and S. C. Porter, Eds.), pp. 138-144. Univ. of Minnesota Press, Minneapolis.

Forman, S. L., Bettis, E. A., III, Kemmis, T. J., and Miller, B. B. (1992). Chronologic evidence for multiple periods of loess deposition during the late Pleistocene in the Missouri and Mississippi River valley, United States: Implications for the activity of the Laurentide Ice Sheet. Palaeogeography, Palaeoclimatology, Palaeoecology 93, 71-83.

Frazee, C. J., Fehrenbacher, J. B., and Krumbein, W. C. (1970). Loess distribution from a source. Soil Science Society of America Proceedings 34, 296-301.

Frye, J. C., and Leonard, A. B. (1952). "Pleistocene geology of Kansas." Kansas Geological Survey Bulletin 99.

Frye, J. C., Glass, H. D., and Willman, H. B. (1968). Mineral zonation of Woodfordian loesses of Illinois. Illinois State Geological Survey Circular 427, 1-44.

Grimley, D. A., Follmer, L. R., and McKay, E. D. (1998). Magnetic susceptibility and mineral zonations controlled by provenance in loess along the Illinois and central Mississippi River valleys. Quaternary Research 49, $24-36$.

Hallberg, G. R. (1979). Wind-aligned drainage in loess in Iowa. Proceedings of the Iowa Academy of Science 86, 4-9.

Hallberg, G. R., Lineback, J. A., Mickelson, D. M., Knox, J. C., Goebel, J. E., Hobbs, H. C., Whitfield, J. W., Ward, R. A., Boellstorf, J. D., Swinehart, J. B., and Dreeszen, V. H. (1991). Quaternary geologic map of the Des Moines $4^{\circ} \times 6^{\circ}$ quadrangle, United States. U.S. Geological Survey Miscellaneous Investigations Series Map I-1420 (NK-15), scale 1: 1,000,000.

Handy, R. L. (1976). Loess distribution by variable winds. Geological Society of America Bulletin 87, 915-927.

Hobbs, W. H. (1943). The glacial anticyclone and the continental glaciers of North America. Proceedings of the American Philosophical Society 86, $368-402$.

Hovan, S. A., Rea, D. K., Pisias, N. G., and Shackleton, N. J. (1989). A direct link between the China loess and marine $\delta^{18} \mathrm{O}$ records: Aeolian flux to the north Pacific. Nature 340, 296-298.

Hutton, C. E. (1947). Studies of loess-derived soils in southwestern Iowa. Soil Science Society of America Proceedings 12, 424-431.

Isarin, R. F. B., Renssen, H., and Koster, E. A. (1997). Surface wind climate during the Younger Dryas in Europe as inferred from aeolian records and model simulations. Palaeogeography, Palaeoclimatology, Palaeoecology 134, 127-148.

Jones, R. L., Ray, B. W., Fehrenbacher, J. B., and Beavers, A. H. (1967). Mineralogical and chemical characteristics of soils in loess overlying shale in northwestern Illinois. Soil Science Society of America Proceedings 31, $800-804$.

Jury, W. M., Dideriksen, R. I., and Fisher, C. S. (1969). "Soil survey of Cass
County, Iowa." U.S. Department of Agriculture, Soil Conservation Service, U.S. Government Printing Office, Washington, DC.

Kleiss, H. J. (1973). Loess distribution along the Illinois soil-development sequence. Soil Science 115, 194-198.

Kutzbach, J. E., Guetter, P. J., Behling, P. J., and Selin, R. (1993). Simulated climatic changes: Results of the COHMAP climate-model experiments. In "Global Climates Since the Last Glacial Maximum." (H. E. Wright et al., Eds.), pp. 24-93. Univ. of Minnesota Press, Minneapolis.

Kutzbach, J. E., Gallimore, R., Harrison, S. P., Behling, P., Selin, R., and Laarif, F. (1998). Climate simulations for the past 21,000 years. Quaternary Science Reviews 17, 473-506.

Leigh, D. S., and Knox, J. C. (1994). Loess of the Upper Mississippi Valley Driftless Area. Quaternary Research 42, 30-40.

Lewis, G. C., and Fosberg, M. A. (1982). Distribution and character of loess and loess soils in southeastern Idaho. Idaho Bureau of Mines and Geology Bulletin 26, 705-716.

Lewis, G. C., Fosberg, M. A., McDole, R. E., and Chugg, J. C. (1975). Distribution and some properties of loess in southcentral and southeastern Idaho. Soil Science Society of America Proceedings 39, 1165-1168.

Lineback, J. A., Bleuer, N. K., Mickelson, D. M., Farrand, W. R., and Goldthwait, R. P. (1983). Quaternary geologic map of the Chicago $4^{\circ} \times 6^{\circ}$ quadrangle, United States. U.S. Geological Survey Miscellaneous Investigations Series Map I-1420 (NK-16), scale 1: 1,000,000.

Maat, P. B., and Johnson, W. C. (1996). Thermoluminescence and new ${ }^{14} \mathrm{C}$ age estimates for late Quaternary loesses in southwestern Nebraska. Geomorphology 17, 115-128.

Mandel, R. D., and Bettis, E. A., III. (1995). Late Quaternary landscape evolution and stratigraphy in eastern Nebraska. In "Geologic Field Trips in Nebraska and Adjacent Parts of Kansas and South Dakota" (C. A. Flowerday, Ed.), pp. 77-90. Conservation and Survey Division, Institute of Agriculture and Natural Resources, Univ. of Nebraska-Lincoln, Guidebook No. 10 .

Martin, C. W. (1993). Radiocarbon ages on late Pleistocene loess stratigraphy of Nebraska and Kansas, central Great Plains, U.S.A. Quaternary Science Reviews 12, 179-188.

Mason, J. A., Nater, E. A., and Hobbs, H. C. (1994). Transport direction of Wisconsinan loess in southeastern Minnesota. Quaternary Research 41, $44-51$.

May, D. W., and Holen, S. R. (1993). Radiocarbon ages of soils and charcoal in late Wisconsinan loess, south-central Nebraska. Quaternary Research 39, $55-58$.

May, D., Swinehart, J. B., Loope, D., and Souders, V. (1995). Late Quaternary fluvial and eolian sediments: Loup River Basin and the Nebraska Sand Hills In "Geologic Field Trips in Nebraska and Adjacent Parts of Kansas and South Dakota" (C. A. Flowerday, Ed.), pp. 13-31. Conservation and Survey Division, Institute of Agriculture and Natural Resources, Univ. of Nebraska-Lincoln, Guidebook No. 10.

McCauley, J. F., Breed, C. S., Grolier, M. J., and MacKinnon, D. J. (1981). The U.S. dust storm of February 1977. Geological Society of America Special Paper 186, 123-147.

McKay, E. D. (1979). Wisconsinan loess stratigraphy of Illinois. In "Wisconsinan, Sangamonian, and Illinoian Stratigraphy in Central Illinois" (L. R. Follmer, E. D. McKay, J. A. Lineback, and D. L. Gross, Eds.), pp. 95-108. Illinois State Geological Survey Guidebook 13.

Muhs, D. R., Aleinikoff, J. N., Stafford, T. W., Jr., Kihl, R., Been, J., Mahan, S. A., and Cowherd, S. D. (1999). Late Quaternary loess in northeastern Colorado, I: Age and paleoclimatic significance. Geological Society of America Bulletin 111, 1861-1875.

Péwé, T. L. (1975). "Quaternary geology of Alaska.” U.S. Geological Survey Professional Paper 835.

Pierce, K. L., Covington, H. R., Williams, P. L., and McIntyre, D. H. (1983). 
Geologic map of the Cotterel Mountains and the northern Raft River Valley, Cassia County, Idaho. U.S. Geological Survey Miscellaneous Investigations Series Map I-1450, scale 1:48,000.

Putman, B. R., Jansen, I. J., and Follmer, L. R. (1988). Loessial soils: Their relationship to width of the source valley in Illinois. Soil Science 146, 241-247.

Rodbell, D. T., Forman, S. L., Pierson, J., and Lynn, W. C. (1997). Stratigraphy and chronology of Mississippi Valley loess in western Tennessee. Geological Society of America Bulletin 109, 1134-1148.

Ruhe, R. V. (1954). Relations of the properties of Wisconsin loess to topography in western Iowa. American Journal of Science 252, 663-672.

Ruhe, R. V. (1969). "Quaternary Landscapes in Iowa." Iowa State Univ. Press, Ames, IA.

Ruhe, R. V. (1983). Depositional environment of late Wisconsin loess in the midcontinental United States. In "Late-Quaternary Environments of the United States" (H. E. Wright, Jr., and S. C. Porter, Eds.), pp. 130-137. Univ. of Minnesota Press, Minneapolis.

Ruhe, R. V., Miller, G. A., and Vreeken, W. J. (1971). Paleosols, loess sedimentation and soil stratigraphy. In "Paleopedology-Origin, Nature and Dating of Paleosols" (D. H. Yaalon, Ed.), pp. 41-59, Israel Universities Press, Jerusalem.

Rutledge, E. M., Holowaychuk, N., Hall, G. F., and Wilding, L. P. (1975). Loess in Ohio in relation to several possible source areas: I. Physical and chemical properties. Soil Science Society of America Proceedings 39, 1125 1132.

Simonson, R. W., and Hutton, C. E. (1954). Distribution curves for loess. American Journal of Science 252, 99-105.
Smith, G. D. (1942). Illinois loess: Variations in its properties and distribution, a pedologic interpretation. University of Illinois Agricultural Experiment Station Bulletin 490, 139-184.

Snowden, J. O., and Priddy, R. R. (1968). Geology of Mississippi loess. Mississippi Geological Survey Bulletin 111, 13-203.

Swineford, A., and Frye, J. C. (1951). Petrography of the Peoria Loess in Kansas. Journal of Geology 59, 306-322.

Swinehart, J. B., Dreeszen, V. H., Richmond, G. M., Tipton, M. J., Bretz, R., Steece, F. V., Hallberg, G. R., and Goebel, J. E. (1994). Quaternary geologic map of the Platte River $4^{\circ} \times 6^{\circ}$ quadrangle, United States. U.S. Geological Survey Miscellaneous Investigations Series Map I-1420 (NK-14), scale $1: 1,000,000$.

Thorp, J., and Smith, H. T. U. (1952). Pleistocene eolian deposits of the United States, Alaska, and parts of Canada. National Research Council Committee for the Study of Eolian Deposits, Geological Society of America, scale $1: 2,500,000$.

Whitfield, J. W., Ward, R. A., Denne, J. E., Holbrook, D. F., Bush, W. V., Lineback, J. A., Luza, K. V., Jensen, K. M., and Fishman, W. D. (1993). Quaternary geologic map of the Ozark Plateau $4^{\circ} \times 6^{\circ}$ quadrangle, United States. U.S. Geological Survey Miscellaneous Investigations Series Map I-1420 (NJ-15), scale 1:1,000,000.

Zeeberg, J. (1998). The European sand belt in eastern Europe - and comparison of Late Glacial dune orientation with GCM simulation results. Boreas $27,127-139$.

Zhang, X. Y., Arimoto, R., and An, Z. S. (1999). Glacial and interglacial patterns for Asian dust transport. Quaternary Science Reviews 18, 811-819. 